\title{
Pyrosequencing, a method approved to detect the two major EGFR mutations for anti EGFR therapy in NSCLC
}

\author{
Sandrine Dufort ${ }^{1,2}$, Marie-Jeanne Richard ${ }^{1,2}$, Sylvie Lantuejoul ${ }^{2,3}$ and Florence de Fraipont ${ }^{1,2^{*}}$
}

\begin{abstract}
Background: Epidermal Growth Factor Receptor (EGFR) mutations, especially in-frame deletions in exon 19 ( $\Delta L R E)$ and a point mutation in exon 21 (L858R) predict gefitinib sensitivity in patients with non-small cell lung cancer. Several methods are currently described for their detection but the gold standard for tissue samples remains direct DNA sequencing, which requires samples containing at least $50 \%$ of tumor cells.

Methods: We designed a pyrosequencing assay based on nested PCR for the characterization of theses mutations on formalin-fixed and paraffin-embedded tumor tissue.

Results: This method is highly specific and permits precise characterization of all the exon 19 deletions. Its sensitivity is higher than that of "BigDye terminator" sequencing and enabled detection of 3 additional mutations in the 58 NSCLC tested. The concordance between the two methods was very good (97.4\%). In the prospective analysis of 213 samples, 7 (3.3\%) samples were not analyzed and EGFR mutations were detected in 18 (8.7\%) patients. However, we observed a deficit of mutation detection when the samples were very poor in tumor cells.

Conclusions: pyrosequencing is then a highly accurate method for detecting $\triangle$ LRE and L858R EGFR mutations in patients with NSCLC when the samples contain at least $20 \%$ of tumor cells.
\end{abstract}

\section{Introduction}

Detection of mutations of the epidermal growth factor receptor (EGFR) gene is critical for predicting the response to therapy with tyrosine kinase inhibitors (TKIs, e.g.: gefitinib and erlotinib) in patients with nonsmall-cell lung cancer (NSCLC) [1]. Practically all mutations are on exons 18 through 21 where they affect the ATP-binding cleft of EGFR [2]. In vitro studies have shown that EGFR mutants have constitutive TK activity and, therefore, a greater sensitivity to anti-EGFR inhibition. Two classes of mutation account for approximately 90\% of EGFR mutations reported to date in lung adenocarcinoma [3]. The class I mutations are in-frame deletions in exon 19, which almost always include aminoacid residues leucine 747 to glutamic acid 749 ( $\triangle \mathrm{LRE}$ ). The second mutation is a single-point mutation in exon

\footnotetext{
* Correspondence: fdefraipont@chu-grenoble.fr

'UM Biochimie des Cancers et Biothérapies, CHU Grenoble, Institut de Biologie et Pathologie, parvis Belledonne, 38043 Grenoble, France Full list of author information is available at the end of the article
}

21 , which substitutes an arginine for a leucine at codon 858 (L858R).

Thus far, the direct DNA sequencing method is the most common and conventional method used for the detection and identification of mutations in tumor cells. However, its sensitivity is suboptimal for clinical tumor samples. Mutant DNA needs to comprise $\geq 25 \%$ of the total DNA to be easily detected [4]. All new techniques claim to be more sensitive with the ability to detect mutations in samples containing $\leq 10 \%$ mutant alleles. Pyrosequencing is a non-electrophoretic real time sequencing technology with luminometric detection [5]. Not only can it detect mutations but it also permits a mutation to be characterized and to quantify the percentage of mutated alleles in a sample. We have previously shown that it is a robust method to characterize the KRAS codon 12 and 13 mutations in paraffinembedded samples in daily practice [6].

Here we also show that pyrosequencing is a simple and sensitive method to detect the two most common mutations of the EGFR TK domain, and demonstrate its
C Biomed Central 
usefulness for detecting such mutations in clinical lung tumor samples, in a large prospective series.

\section{Materials and methods Cell lines}

The human lung cancer cell lines NCI-H1650 and NCIH1975 were obtained from the American Type Culture Collection (ATCC). Both cell lines were cultured in RPMI 1640 supplemented with 10\% fetal bovine serum at $37^{\circ} \mathrm{C}$ in air containing $5 \% \mathrm{CO}_{2}$. Peripheral Blood Lymphocytes (PBL) used as negative control were obtained from healthy volunteers.

\section{Clinical samples}

Between $1^{\text {st }}$ January and 30 June 2010, 213 tumor samples were collected from consecutive patients with an advanced lung adenocarcinoma, DNA extracted and their EGFR mutation status determined for selection for anti EGFR treatments by clinicians. All analyses were conducted with full respect of patients' rights to confidentiality and according to procedures approved by the local authorities responsible for ethics in research. All samples were histologically analyzed by an experienced thoracic pathologist and classified according to the WHO classification of lung cancer. For each sample, the percent of tumor cells was determined.

\section{DNA extraction}

The DNAeasy kit (Qiagen) was used according to the manufacturer's instructions to extract genomic DNA from cells and from tumor tissues. A prolonged $(48 \mathrm{H})$ proteinase $\mathrm{K}$ digestion was used for paraffin-embedded tissues [6].

\section{PCR amplification of exons 19 and 21 of the EGFR gene}

PCR and sequencing primers were designed using the PSQ assay design (Biotage) and are described in table 1. $100 \mathrm{ng}$ of tumor DNA was amplified using a nested PCR to amplify almost all samples independent of the type of tissue fixative or of the fixative conditions. The first PCR product was amplified at $58^{\circ} \mathrm{C}$ for 20 (exon 19) or 10 (exon 21) cycles. The second PCR procedure was carried out in a total volume of $50 \mu \mathrm{l}$ containing $2 \mu \mathrm{l}$ of the first PCR, $20 \mathrm{pmol}$ of each primer, $1.5 \mathrm{mmol} / \mathrm{l} \mathrm{MgCl}_{2}$ and $1.25 \mathrm{U}$ of FastStart Taq DNA polymerase (Roche). PCR conditions consisted of initial denaturing at $95^{\circ} \mathrm{C}$ for $15 \mathrm{~min}, 45$ cycles at $95^{\circ} \mathrm{C}$ for 20 s, $62^{\circ} \mathrm{C}$ (exon 19) or $61^{\circ} \mathrm{C}$ (exon 21) for $20 \mathrm{~s}, 72^{\circ} \mathrm{C}$ for $20 \mathrm{~s}$ and a final extension at $72^{\circ} \mathrm{C}$ for $10 \mathrm{~min}$. The PCR products $(10 \mu \mathrm{l})$ were analyzed by electrophoresis in a $3 \%$ agarose gel to confirm the successful amplification of the 180-bp or the 195-bp PCR product.

\section{Pyrosequencing analysis}

$40 \mu \mathrm{l}$ of PCR product were bound to streptavidin Sepharose HP (GE Healthcare), purified, washed, denatured using a $0.2 \mathrm{~mol} / \mathrm{l} \mathrm{NaOH}$ solution, and washed again. Then $0.3 \mu \mathrm{mol} / \mathrm{l}$ pyrosequencing primer was annealed to the purified single-stranded PCR product and the pyrosequencing was performed on a PyroMark ID system (Qiagen) following the manufacturer's instructions. The nucleotide dispensation order was GTATCAGACATGAC for analysis of exon 19 and CTGCGTGTCA for analysis of exon 21.

\section{Results}

Pyrosequencing assay of exon 19 deletions

In order to test the pyrosequencing method for the analysis of exon 19 deletions, we used DNA from the NCIH1650 cell line as positive control and DNA extracted from human peripheral blood lymphocytes (PBL) as wild-type control. We choose a particular pyrosequencing program with the oligonucleotide dispensation order (GTATCAGACATGAC) because it permits to distinguish wild type and mutated alleles (table 2) generating for each sample a specific pyrogram (Figure 1A and $1 \mathrm{~B}$ and Figure 2). These pyrograms correspond to a mix of wild type and mutated alleles. We quantitatively evaluated the exon 19 deletion (c.2235-2249del; p. Glu746-Ala750del) by determining the ratio between the peak areas of the two adenines dispensed in positions 6 $\left(A_{6}\right)$ and $8\left(A_{8}\right)$. We tested the reproducibility of the

Table 1 Sequences of primers used for pyrosequencing analysis

\begin{tabular}{|c|c|c|c|c|}
\hline & \multirow{2}{*}{$\begin{array}{c}\text { Exon } 19 \\
\text { primer sequence }\end{array}$} & \multicolumn{3}{|c|}{ Exon 21} \\
\hline & & $\begin{array}{c}\mathrm{T}^{\circ} \text { of } \\
\text { hybridation }\end{array}$ & primer sequence & $\begin{array}{c}\mathrm{T}^{\circ} \text { of } \\
\text { hybridation }\end{array}$ \\
\hline First & 5'-GCAATATCAGCCTTAGGTGCGGCTC-3' & $58^{\circ} \mathrm{C}$ & 5'-CTAACGTTCGCCAGCCATAAGTCC-3' & $58^{\circ} \mathrm{C}$ \\
\hline PCR & 5'-CATAGAAAGTGAACATTTAGGATGTG-3' & & $\begin{array}{l}\text { 5'- } \\
\text { GCTGCGAGCTCACCCAGAATGTCTGG-3' }\end{array}$ & \\
\hline second & 5'-CATGTGGCACCATCTCACAAT-3' & $62^{\circ} \mathrm{C}$ & 5'-GAATTCGGATGCAGAGCTTCTT-3' & $61^{\circ} \mathrm{C}$ \\
\hline PCR & $\begin{array}{l}\text { 5'-Biotin-CCCACA CAGCAA } \\
\text { AGCAGAAACT-3' }\end{array}$ & & 5'-Biotin-CTTTCTCTTCCGCACCCA & \\
\hline $\begin{array}{l}\text { primer for sequence } \\
\text { reaction }\end{array}$ & 5'-TAAAATTCCCGTCGC-3' & & 5'-CATGTCAAGACTACAGATT-3' & \\
\hline
\end{tabular}


Table 2 Sequencing of wild type and mutated alleles with a particular program of pyrosquencing

\begin{tabular}{|c|c|c|c|c|c|c|c|c|c|c|c|c|c|c|c|}
\hline \multicolumn{2}{|c|}{ nucleotide dispensation during pyrosequencing } & G & $T$ & A & $\mathrm{T}$ & $\mathrm{C}$ & A & G & A & $\mathrm{C}$ & A & $\mathrm{T}$ & G & A & $\mathrm{C}$ \\
\hline & WT & & $T$ & A & $T$ & $\mathrm{C}$ & $A A$ & GG & $A A$ & & & $\mathrm{TT}$ & & $A A$ & \\
\hline allelic & c.2235-2249del & & $\mathbf{T}$ & A & $\mathbf{T}$ & $\mathrm{C}$ & $\mathbf{A A} A A$ & & & C & $A$ & $T$ & & & C \\
\hline \multirow[t]{3}{*}{ sequence of } & c.2236-2250del & & $\mathbf{T}$ & A & $\mathbf{T}$ & $\mathrm{C}$ & AA & $\mathbf{G}$ & $A$ & $C$ & A & $T$ & & & C \\
\hline & c. $2237-2251 \mathrm{del}$ & & $\mathrm{T}$ & A & $T$ & $\mathrm{C}$ & $A A$ & GG & & $C$ & $A$ & $T$ & & & C \\
\hline & c.2240-2257del & & $\mathrm{T}$ & A & $\mathrm{T}$ & $\mathrm{C}$ & $A A$ & GG & $A A$ & & & $T$ & & & C \\
\hline
\end{tabular}

Bold letters correspond to the nucleotides identical in wild type and mutated alleles; italic letters correspond to the nucleotides specific of mutated alleles.

technique by analyzing each DNA in 20 consecutive and independent runs. We found an $\mathrm{A}_{6} / \mathrm{A}_{8}$ ratio of $1.06 \pm$ 0.04 for the wild type sample and $4.59 \pm 0.33$ for the sample with the deletion. The relative standard deviation (RSD) was respectively $3.9 \%$ and $7.2 \%$. Thus, a sample could be considered as mutated if $\mathrm{A}_{6} / \mathrm{A}_{8}$ was superior to 1.2 (corresponding to [the mean +3 standard deviations] of the wild type sample). To demonstrate the assay sensitivity, we also quantified the $A_{6} / A_{8}$ ratio in various mixtures $(10 / 0,9 / 1,8 / 2,7 / 3,6 / 4,5 / 5,4 / 6,3 / 7$, $2 / 8,1 / 9$ and $0 / 10$ ) of DNA from the NCI-H1650 cell line with DNA from peripheral blood lymphocytes (Figure $1 C$ ). Each mixture was analyzed 5 times in the same run and we found an $\mathrm{A}_{6} / \mathrm{A}_{8}$ ratio varying from $5.27 \pm$ 0.38 (mixture $10 / 0$ ) to $1.11 \pm 0.05$ (mixture $0 / 10$ ). We determined that all the mixtures containing at least $20 \%$ of NCI-H1650 DNA have an $\mathrm{A}_{6} / \mathrm{A}_{8}$ ratio superior to 1.2 and could be considered as mutated.

Moreover, the pyrosequencing program that analyzed the deletions in exon 19 was designed to detect almost all types of deletion (figure 2). In comparison with the graph obtained with the wild type sample, the diminution of several peaks (marked *) and the emergence of new ones (marked $\diamond$ ) were considered as specific of a deletion (table 2).

\section{Pyrosequencing assay of L858R exon 21 point mutation}

L858R-specific pyrosequencing was performed using the NCI-H1975 cell line and a percentage of T > G mutation was determined (Figure 3). The result obtained with 20 consecutive runs, was $46.2 \pm 3 \%$ with good reproducibility $(\mathrm{RSD}=6.4 \%)$. We also determined the

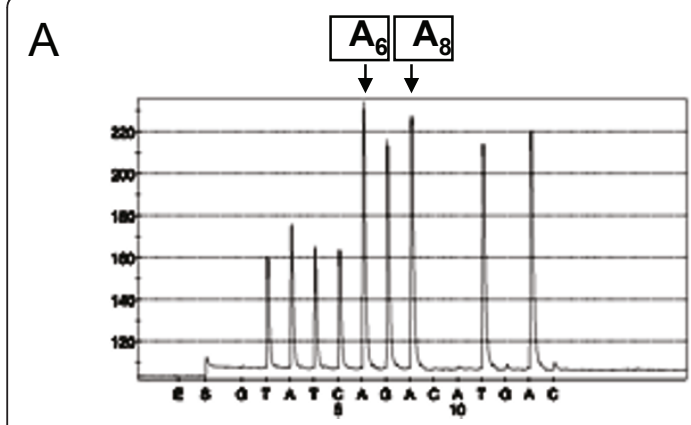

$$
\mathrm{A}_{6} / \mathrm{A}_{8}=1.06 \quad 0.04 ; \mathrm{RSD}=3.9 \%
$$

$B$

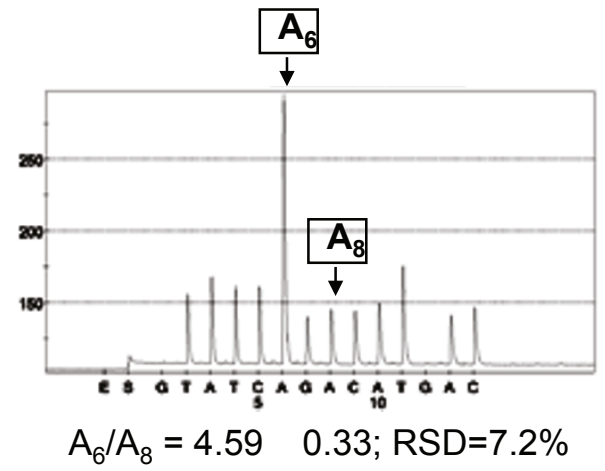

C

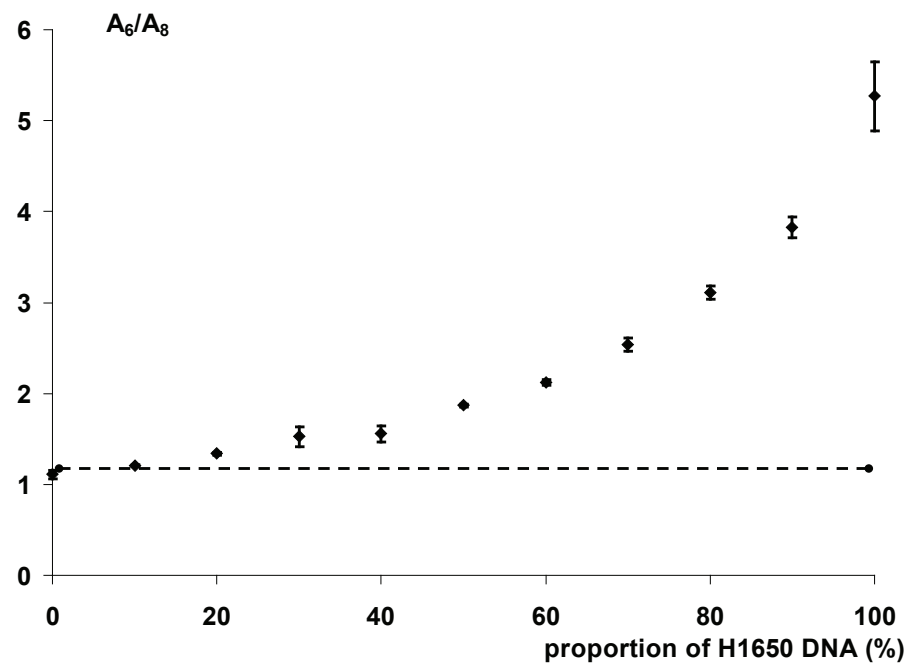

Figure 1 Analysis of exon 19 deletions by pyrosequencing. The analysis was performed with PBL DNA (A) as wild-type control and with NCl-H1650 DNA (B) as deletion control. The deletion was quantified by determining the ratio between the $A_{8}$ and $A_{6}$ peak areas. (C) The sensitivity was characterized by measuring A8/A6 ratio in different mixtures of NCl-H1650 DNA and PBL DNA. 


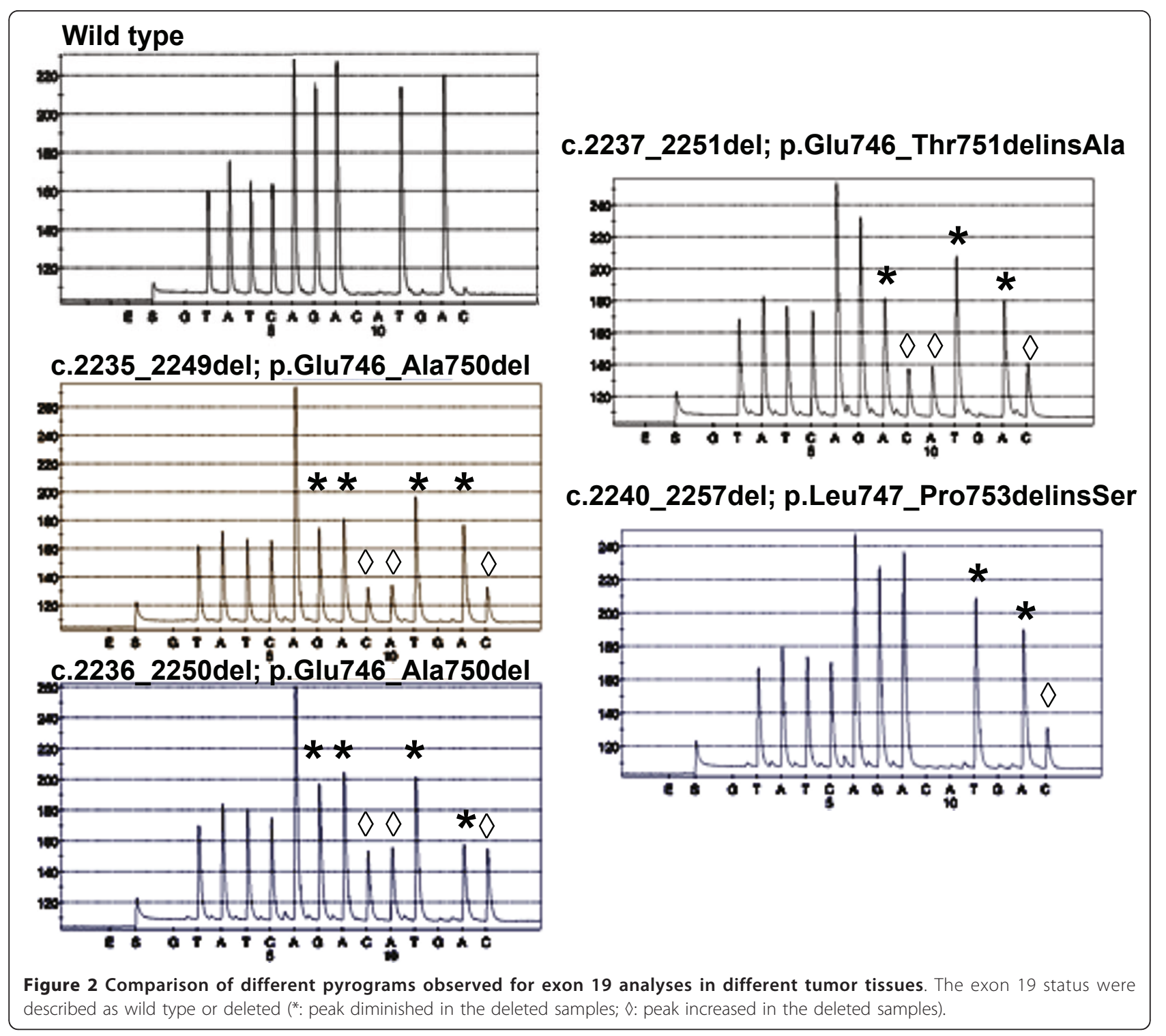

repeatability and the sensitivity of this method with various mixtures $(10 / 0,9 / 1,8 / 2,7 / 3,6 / 4,5 / 5,4 / 6,3 / 7,2 / 8$, $1 / 9$ and $0 / 10$ ) of DNA from the NCI-H1975 cell line and DNA from peripheral blood lymphocytes (Figure $3 \mathrm{C})$. We detected the percentage of $\mathrm{T}>\mathrm{G}$ mutation with a linear variation $\left(R^{2}=0.99\right)$ from $39.6 \pm 0.6 \%$ (mixture 10/0) to $7.7 \pm 1.7 \%$ (mixture $4 / 6$ ) and a relative standard deviation varying from 1.4 to $15.9 \%$. We also determined $\mathrm{a} \%$ of mutation for the mixtures $3 / 7$ and $2 / 8$ with a CV largely higher then $20 \%$.

\section{EGFR mutation in tumor samples}

We compared the results obtained previously by conventional BigDye Terminator sequencing [7] using the method described by Pao et al [8] and those obtained by pyrosequencing 58 of these tumor samples (Table 3). All mutated samples were confirmed twice, starting from independent polymerase chain reactions. We observed a very high concordance between the two methods (56/58 (96.6\%) for exon 19 and 57/58 (98.3\%) for exon 21 analysis). For 3 samples (3/58; 5\%), results were discordant and mutations were detected only by pyrosequencing and not by Big Dye terminator sequencing, reflecting the lower sensitivity of the classical sequencing method. Indeed, the two samples with an exon 19 deletion have an $\mathrm{A}_{6} / \mathrm{A}_{8}$ ratio of 1.7 and 1.8 which correspond to less of $25 \%$ of mutated alleles (figure 1C). For the sample with a L858R mutation detected only by pyrosequencing, we found that only $22.5 \%$ of the DNA was mutated.

We then determined the EGFR status of 213 patients with advanced or metastatic lung adenocarcinomas for 


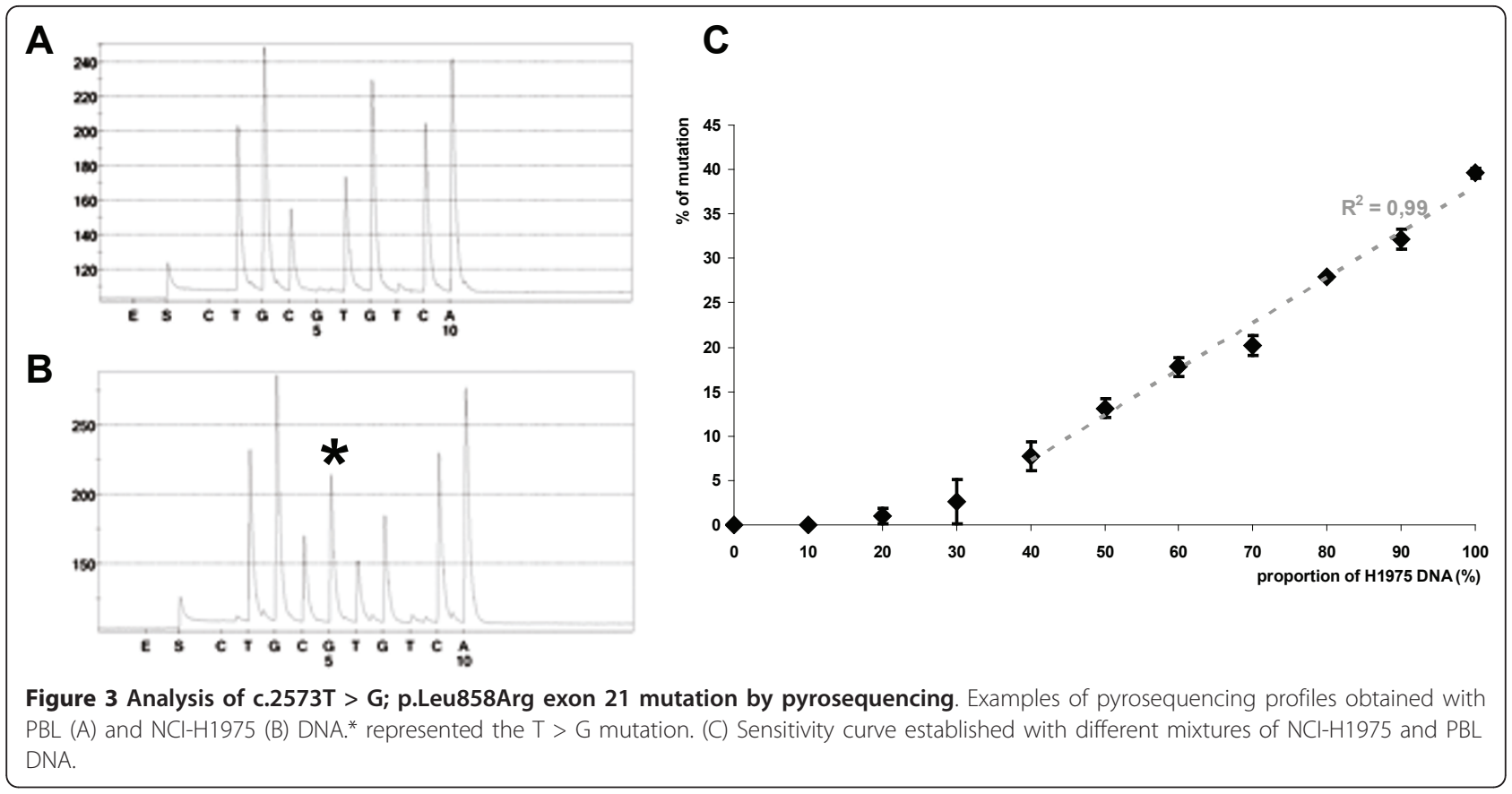

selection of to anti EGFR therapies (table 4). Seven (3.3\%) samples were inconclusive due to poor DNA quality with no DNA amplification. Of the 206 remaining samples, 18 EGFR mutations were detected ( 8 of exon 19 and 10 of exon 21) (18/206; 8.7\%). Among these 206 specimens, 36 had less than $20 \%$ of tumor cells and only one with a mutation was detected $(1 / 36$; $2.8 \%$ ). For the 170 specimens containing more than $20 \%$ of tumor cells, 17 with mutations were found (17/170; $10 \%)$.

\section{Discussion}

Pyrosequencing is sensitive and enables accurate detection of mutations. A previous study has described the capacity of this method to detect small insertions [9] but this study is the first to demonstrate the application of pyrosequencing to exon 19 deletions. Analysis of exon 21 by pyrosequencing had been succinctly described by Takano et al. $[10,11]$, but without any data about the specificity, the repeatability or the sensitivity.

We first investigated the characteristics of EGFR mutations in the lung cancer cell lines NCI-H1650 and NCI-H1975 and used them as positive controls for the deletion in exon19 and the point mutation in exon 21 respectively. Moreover we used the DNA of these cells mixed with DNA isolated from blood samples from healthy volunteers to evaluate the basic properties of our novel method. We didn't observe strict linearity because the two cell lines (NCI-H1650 and NCI-H1975) have respectively 4 and 2.8 EGFR gene copies [12] but we found good sensitivity.

In routine daily practice fixed paraffin-embedded specimens, most often of small size, are the only samples available for both diagnosis and molecular analyses. The DNA is frequently fragmented, which could hamper PCR amplification. However, the PCR conditions described in this study allowed analysis of $96.7 \%$ of the paraffin-embedded tissues whatever the type of fixative used or the duration of the fixation. When the samples could be amplified and analyzed, results were concordant (97.4\%) with those obtained by conventional BigDye terminator sequencing. The difference in sensitivity between the two methods is illustrated by the 3 samples characterized as mutated only by pyrosequencing. The frequency of deletions in exon 19 and mutations in exon 21 among the NSCLC patients was almost

Table 3 Comparison of EGFR status (wild type (WT) or mutant (M)) of exon 19 and exon 21 determined by big dye sequencing or by pyrosequencing on 58 NSCLC tissues

\begin{tabular}{|c|c|c|c|c|c|c|c|}
\hline \multirow[t]{2}{*}{ Exon 19} & & \multicolumn{2}{|c|}{ big dye sequencing } & \multirow[t]{2}{*}{ Exon 21} & & \multicolumn{2}{|c|}{ big dye sequencing } \\
\hline & & WT & $M$ & & & WT & $M$ \\
\hline \multirow[t]{2}{*}{ pyrosequencing } & WT & 47 & / & pyrosequencing & WT & 53 & / \\
\hline & $M$ & 2 & 9 & & $M$ & 1 & 4 \\
\hline
\end{tabular}


Table 4 Prospective evaluation of the EGFR status of exons 19 and 21

\begin{tabular}{cccccc}
\hline \% of tumoral & $\begin{array}{c}\text { tumoral samples }(\mathrm{n}= \\
\text { 206) }\end{array}$ & \multicolumn{4}{c}{ EGFR mutations $(\mathrm{n}=$} \\
cells & number & $\%$ & exon 19 & exon 21 & \% \\
\hline$<20 \%$ & 36 & 17.5 & 0 & 1 & 2.8 \\
from 20 to $50 \%$ & 98 & 47.6 & 3 & 6 & 9.2 \\
$>50 \%$ & 72 & 35 & 5 & 3 & 11.1 \\
\hline
\end{tabular}

Samples may contain at least $20 \%$ of tumor cells to allow a correct detection of mutations

consistent with the corresponding values reported in Caucasian populations [13]. These samples were also analyzed for KRAS mutations because (i) EGFR and KRAS mutations are mutually exclusive in NSCLC and (ii) emerging data suggest that KRAS mutations are negative predictors of benefit from both adjuvant chemotherapy and anti-EGFR-directed therapies $[12,14,15]$. We found $26.7 \%$ of the samples with a KRAS mutation (data not shown). This is also in accordance with the literature [14] and validated our cohort as being well representative. We found 8 exon 19 deletions and 10 exon 21 mutations. These results were in accordance with those described by Tanaka et al. [16]. They noticed that exon 19 deletions were significantly associated with a male gender. In our cohort, 15 of the 18 patients with EGFR mutations were female.

We observed a deficit in mutation detection when the samples were very poor in tumor cells whereas the others could be accurately analyzed. As only bronchial or trans-thoracic fine needle biopsies are usually available in the medical setting of patients with advanced stage NSCLC (around 90\% of the samples analyzed here, with only $10 \%$ being surgical specimens), these results demonstrate the need for a pathologist's expertise to qualify the samples and perform microdissection if samples contain less than $20 \%$ of tumor cells. Indeed, Masago et al. [17] have demonstrated that results could be obtained from biopsy specimens only if the quantity of the specimen is sufficient to make a pathological diagnosis and if cancer cells were carefully selected. However, microdissection is very time-consuming and it is not always possible. Alternatively, methods such as peptide nucleic acid-locked nucleic acid PCR clamp $[18,19]$ or real-time PCR based on scorpion primers coupled with the Amplified Refractory Mutation System (ARMS) [20] have a sensitivity around $1 \%$ of cancer cells. However, they could be difficult to use in routine clinical assay because they require special equipments and expensive reagents.

\section{Conclusions}

The present pyrosequencing method is sufficiently sensitive and specific to enable the detection of the two major
TKI-sensitive mutations in a large majority of the DNA extracted from paraffin-embedded clinical samples.

\section{Acknowledgements and funding}

Excellent technical support was provided by Emilie Bonin, Monique Delon, Valérie Konik-Mathevet, Maryse Samuel and Odile Vermeulen. We also acknowledge the Department of Cytology and Pathology for tumor sample preparations. We thank Dr Alison Foote for correcting our English usage. This project was supported by the clinical research direction of the Grenoble's hospital, INCa (the French National Cancer Institute) and the French ministry of health initiated the ERMETIC project.

\section{Author details}

'UM Biochimie des Cancers et Biothérapies, CHU Grenoble, Institut de Biologie et Pathologie, parvis Belledonne, 38043 Grenoble, France. ${ }^{2}$ Centre de recherche INSERM/UJF U823, Institut Albert Bonniot, Rond-point de la Chantourne, 38709 La Tronche cedex 9, France. ${ }^{3}$ Département d'Anatomie et Cytologie Pathologiques, CHU Grenoble, Institut de Biologie et Pathologie, parvis Belledonne, 38043 Grenoble, France.

\section{Authors' contributions}

SD carried out the molecular analysis, MJR participated in the design of the study and drafted the manuscript, SL carried out immunohistochemestry analysis, FdeF designed the study, carried out the molecular analysis and drafted the manuscript. All authors reviewed the draft manuscript, read and approved the final version for submission.

\section{Competing interests}

The authors declare that they have no competing interests.

Received: 7 March 2011 Accepted: 16 May 2011 Published: 16 May 2011

\section{References}

1. Govindan R: INTERESTing biomarker to select IDEAL patients for epidermal growth factor receptor tyrosine kinase inhibitors: yes, for EGFR mutation analysis, others, I PASS. J Clin Oncol 28:713-715.

2. Gazdar AF: Personalized medicine and inhibition of EGFR signaling in lung cancer. N Engl J Med 2009, 361:1018-1020.

3. Gazdar AF: Activating and resistance mutations of EGFR in non-small-cell lung cancer: role in clinical response to EGFR tyrosine kinase inhibitors. Oncogene 2009, 28(Suppl 1):S24-31.

4. Pao W, Ladanyi M: Epidermal growth factor receptor mutation testing in lung cancer: searching for the ideal method. Clin Cancer Res 2007, 13:4954-4955.

5. Ronaghi $M$, Uhlen $M$, Nyren P: A sequencing method based on real-time pyrophosphate. Science 1998, 281:363-365.

6. Dufort S, Richard MJ, de Fraipont F: Pyrosequencing method to detect KRAS mutation in formalin-fixed and paraffin-embedded tumor tissues. Anal Biochem 2009, 391:166-168.

7. Beau-Faller M, Degeorges A, Rolland E, Mounawar M, Antoine M, Poulot V, Mauguen A, Barbu V, Coulet F, Pretet JL, Bieche I, Blons H, Boyer JC, Buisine MP, de Fraipont F, Lizard S, Olschwang S, Saulnier P, PrunierMirebeau D, Richard N, Danel C, Brambilla E, Chouaid C, Zalcman G, Hainaut P, Michiels S, Cadranel J: Cross-Validation Study for Epidermal Growth Factor Receptor and KRAS Mutation Detection in 74 Blinded Non-small Cell Lung Carcinoma Samples: A Total of 5550 Exons Sequenced by 15 Molecular French Laboratories (Evaluation of the EGFR Mutation Status for the Administration of EGFR-TKIs in Non-Small Lung Carcinoma [ERMETIC] Project-Part 1). J Thorac Oncol 2011.

8. Pao W, Miller V, Zakowski M, Doherty J, Politi K, Sarkaria I, Singh B, Heelan R, Rusch V, Fulton L, Mardis E, Kupfer D, Wilson R, Kris M, Varmus H: EGF receptor gene mutations are common in lung cancers from "never smokers" and are associated with sensitivity of tumors to gefitinib and erlotinib. Proc Natl Acad Sci USA 2004, 101:13306-13311.

9. Guo DC, Qi Y, He R, Gupta P, Milewicz DM: High throughput detection of small genomic insertions or deletions by Pyrosequencing. Biotechnol Lett 2003, 25:1703-1707.

10. Fukui T, Ohe Y, Tsuta K, Furuta K, Sakamoto H, Takano T, Nokihara H, Yamamoto N, Sekine I, Kunitoh H, Asamura H, Tsuchida T, Kaneko M, 
Kusumoto M, Yamamoto S, Yoshida T, Tamura T: Prospective study of the accuracy of EGFR mutational analysis by high-resolution melting analysis in small samples obtained from patients with non-small cell lung cancer. Clin Cancer Res 2008, 14:4751-4757.

11. Takano T, Ohe Y, Sakamoto H, Tsuta K, Matsuno Y, Tateishi U, Yamamoto S, Nokihara H, Yamamoto N, Sekine I, Kunitoh H, Shibata T, Sakiyama T, Yoshida T, Tamura T: Epidermal growth factor receptor gene mutations and increased copy numbers predict gefitinib sensitivity in patients with recurrent non-small-cell lung cancer. J Clin Oncol 2005, 23:6829-6837.

12. Gandhi J, Zhang J, Xie Y, Soh J, Shigematsu H, Zhang W, Yamamoto H, Peyton M, Girard L, Lockwood WW, Lam WL, Varella-Garcia M, Minna JD, Gazdar AF: Alterations in genes of the EGFR signaling pathway and their relationship to EGFR tyrosine kinase inhibitor sensitivity in lung cancer cell lines. PLoS One 2009, 4:e4576.

13. Pircher A, Ploner F, Popper H, Hilbe W: Rationale of a relaunch of gefitinib in Caucasian non-small cell lung cancer patients. Lung Cancer 69:265-271.

14. Riely GJ, Marks J, Pao W: KRAS mutations in non-small cell lung cancer. Proc Am Thorac Soc 2009, 6:201-205.

15. Roberts PJ, Stinchcombe TE, Der CJ, Socinski MA: Personalized Medicine in Non-Small-Cell Lung Cancer: Is KRAS a Useful Marker in Selecting Patients for Epidermal Growth Factor Receptor-Targeted Therapy? I Clin Oncol 2011.

16. Tanaka T, Matsuoka M, Sutani A, Gemma A, Maemondo M, Inoue A, Okinaga S, Nagashima M, Oizumi S, Uematsu K, Nagai Y, Moriyama G, Miyazawa H, Ikebuchi K, Morita S, Kobayashi K, Hagiwara K: Frequency of and variables associated with the EGFR mutation and its subtypes. Int $J$ Cancer 126:651-655.

17. Masago K, Fujita S, Mio T, Ichikawa M, Sakuma K, Kim YH, Hatachi Y, Fukuhara A, Kamiyama K, Sonobe M, Miyahara R, Date H, Mishima M: Accuracy of epidermal growth factor receptor gene mutation analysis by direct sequencing method based on small biopsy specimens from patients with non-small cell lung cancer: analysis of results in 19 patients. Int I Clin Oncol 2008, 13:442-446.

18. Nagai Y, Miyazawa H, Huqun, Tanaka T, Udagawa K, Kato M, Fukuyama S, Yokote A, Kobayashi K, Kanazawa M, Hagiwara K: Genetic heterogeneity of the epidermal growth factor receptor in non-small cell lung cancer cell lines revealed by a rapid and sensitive detection system, the peptide nucleic acid-locked nucleic acid PCR clamp. Cancer Res 2005, 65:7276-7282

19. Tanaka T, Nagai Y, Miyazawa H, Koyama N, Matsuoka S, Sutani A, Huqun, Udagawa K, Murayama Y, Nagata M, Shimizu Y, Ikebuchi K, Kanazawa M, Kobayashi K, Hagiwara K: Reliability of the peptide nucleic acid-locked nucleic acid polymerase chain reaction clamp-based test for epidermal growth factor receptor mutations integrated into the clinical practice for non-small cell lung cancers. Cancer Sci 2007, 98:246-252.

20. Kimura H, Kasahara K, Kawaishi M, Kunitoh H, Tamura T, Holloway B, Nishio K: Detection of epidermal growth factor receptor mutations in serum as a predictor of the response to gefitinib in patients with nonsmall-cell lung cancer. Clin Cancer Res 2006, 12:3915-3921.

doi:10.1186/1756-9966-30-57

Cite this article as: Dufort et al:: Pyrosequencing, a method approved to detect the two major EGFR mutations for anti EGFR therapy in NSCLC. Journal of Experimental \& Clinical Cancer Research 2011 30:57.

\section{Submit your next manuscript to BioMed Central and take full advantage of:}

- Convenient online submission

- Thorough peer review

- No space constraints or color figure charges

- Immediate publication on acceptance

- Inclusion in PubMed, CAS, Scopus and Google Scholar

- Research which is freely available for redistribution 